\title{
Clinical management of Hypoplasic Amelogenesis Imperfecta: a challenge for multidisciplinary team. A case report
}

\author{
Manejo clínico de la amelogénesis imperfecta hipoplásica: un desafío \\ para el equipo multidisciplinar. Reporte de un caso
}

Alfredo Natera-G. ${ }^{1}$, Maria Gabriela Acosta-de CAMargo ${ }^{2}$, John Mangles ${ }^{3}$

\footnotetext{
Dentist. Magister in Statistics in Social data. Professor in Department of Operative Dentistry, Universidad Central de Venezuela. Caracas, Venezuela. (DD 0000-0002-7823-9383

2 PhD in Dentistry. Universidad Central de Venezuela. Specialist in Pediatric Dentistry University Santa Maria. Professor in the Department of Pediatric Dentistry, Universidad de Carabobo. Valencia, Venezuela. (D) 0000-0001-7615-918X

3 Dentist. Universidad Central de Venezuela. Caracas. Venezuela†
}

\begin{abstract}
Amelogenesis imperfecta $(\mathrm{Al})$ refers to a group of rare genetic disorders that involve tooth development and are passed down through families. Hypoplasic Al phenotypes include the absence of enamel as a result of a defect in the secretory stage. This case report describes the diagnosis and treatment of a patient

Keywords:

hypoplasic amelogenesis imperfecta, direct resin, veneers with hypoplastic Al. The clinical implications include sensitive teeth, functional problems, and aesthetic complaining. The diagnosis was done through history, clinical examination and imaging. The intervention was performed by Direct Resin Veneers. This treatment showed to improve occlusion, esthetics, and selfimage of the teenager. The satisfactory clinical result has made it possible to avoid more invasive and expensive treatments.
\end{abstract}

\begin{abstract}
Resumen
La amelogénesis imperfecta $(\mathrm{AI})$ se refiere a un grupo de trastornos genéticos raros que involucran el desarrollo de los dientes y se transmiten de padres a hijos. Los fenotipos de Al hipoplásicos incluyen la ausencia de esmalte como resultado de un defecto en la etapa secretora. Este reporte de caso clínico describe el diagnóstico y tratamiento de un paciente con Al tipo hipoplásica. Las implicaciones clínicas incluyen dientes sensibles, problemas funcionales y quejas estéticas. El diagnóstico se realizó mediante anamnesis, exploración clínica e imagenología. La intervención fue realizada con carillas directas de resina. Este tratamiento demostró mejoras en la oclusión, la estética y la autoimagen del adolescente. El resultado clínico satisfactorio permitió evitar tratamientos más invasivos y costosos.
\end{abstract}

Palabras clave: amelogénesis imperfecta hipoplásica, resina directa, carillas

\section{INTRODUCTION}

Amelogenesis Imperfecta $(\mathrm{Al})$ refers to a group of genetic alterations of the normal structure of the dental enamel that disturbs its clinical appearance. Al is classified as hypoplastic, hypocalcified, and hypomaturation. These abnormalities may exist in isolation or associated

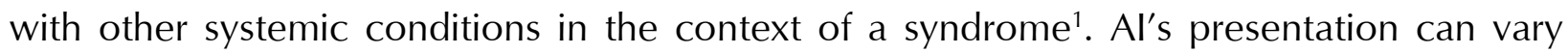
depending on the type and severity ${ }^{2}$, teeth affected may be discolored, sensitive or prone to disintegration ${ }^{3}$. This condition is characterized by abnormal enamel formation caused by gene mutations that alter the quality and/or quantity of enamel ${ }^{4}$. Impaired esthetics, tooth 
hypersensitivity, wide pulp chamber, higher risk of dental caries, and decreased occlusal vertical dimension are among the challenges faced in the management of Al. Dental anomalies associated with Al include enamel disorders, anterior open bite, pulpal calcifications, delayed eruption of teeth, pathological root and crown resorption, and taurodontism ${ }^{5,6}$.

In an effort to classify the disease, particular phenotypes have been defined but this approach can be confounded by mixed phenotypes. Hypoplastic Al describes thin but mineralized enamel, or in extreme cases, the complete absence of enamel, that results from failure during the secretory stage. Hypomineralized $\mathrm{Al}$ is caused by maturation stage failure; giving rise to enamel that is of full thickness but is weak and fails prematurely. The hypomineralized phenotype can be further subdivided into hypomaturation and hypocalcified Al. The former is caused by incomplete removal of protein from the enamel matrix and produces brittle enamel, while the latter is characterized by insufficient transport of calcium ions into the developing enamel and produces soft enamel ${ }^{7-9}$.

Al passes down through families as a dominant trait. This condition is characterized by abnormal enamel formation caused by gene mutations that alter the quality and/or quantity of enamel. The literature review showed that mutations in 16 genes (AMELX, AMBN, ENAM, LAMB3, LAMA3, ACPT, FAM83H, C4ORF26, SLC24A4, ITGB6, AMTN, MMP20, KLK4, WDR72, STIM1, GPR68) are responsible for non-syndromic hypoplastic, hypocalcified, or hypomaturation $\mathrm{Al}^{1}$. FAM20A is essential for amelogenesis, but is dispensable for dentinogenesis ${ }^{10}$. Amelogenin is the most abundant enamel matrix protein, most of which is encoded by the amelogenin gene in the X-chromosome (AMELX). More than 16 alternative splicing transcripts have been identified in the murine Amelx gene ${ }^{2}$.

Clinically the presentation of the Al can have variety of presentation. This condition can impact both primary and permanent dentition ${ }^{7}$. The clinical implications of Al are significant for patients and clinicians. They include esthetic involvement, hypersensitive teeth, mastication impairment and psychosocial affections. The varying etiology of Al conjures a wide array of clinicals features whose restorative management poses a challenge for dentist ${ }^{11}$.

The treatment for $\mathrm{Al}$ depends on the severity of the problem and age of the patient. It is crucial to plan a proper intervention, which requires collaboration among dental specialties to execute comprehensive dental treatment in order to provide a long-term solution with adequate esthetics ${ }^{4}$. The diagnosis and planification of plans for coverage can be significative in the life of a patient with $\mathrm{Al}$, while some of them have received proper canalization others can spend many times without satisfying results.

Currently, there are no defined therapy recommendations available for patients suffering from Al. The mentioned therapies are more or less equal but no comprehensive therapy recommendation is evident. When treating patients suffering from $\mathrm{Al}$, a comprehensive therapy of almost every dental discipline has to be considered. The earlier the diagnosis of $\mathrm{Al}$ is confirmed, the better the outcome is ${ }^{12}$. Management of a patient with $\mathrm{Al}$ involves a complex interplay of various factors ${ }^{5,13}$. To design an appropriate treatment plan, factors such as the quality and quantity of the enamel, age and socioeconomic status of the patient, the type and severity of the disorder, and the intraoral status should be taken into consideration ${ }^{14}$. 
In order to achieve these goals a stepwise approach to treatment planning is required starting with the most conservative but aesthetically acceptable treatment ${ }^{15}$.

Having Al has a marked impact on the psychosocial health of affected people comparable with the impact of systemic health conditions, especially at younger ages ${ }^{16}$. Negative emotions that occur in adolescents when disagreement is perceived in the dentolabial aesthetics, will affect the social and intellectual life of the teenager. Multidisciplinary team is useful to collect, manage knowledge of self-esteem, self-concept and psychological formation of these patients ${ }^{17}$.

\section{Case presentation}

This is a case report of a male patient who is 12 years old, born of non-consanguineous parents. He is the product of first birth of a mother of 33 years old, whose prenatal and medical history was non contributory. The mother reported a normal pregnancy and delivery without complications. As an important antecedent she informed that the father had discolored teeth, but not so marked as the son. No other sibling or family had the enamel defect. He did not report any renal disease, a renal ultrasound showed no images of renal affection and laboratory exams, including calcium, phosphate, and creatinine levels were below the average.

The current case report presents a patient affected by Al whose diagnosis was unclear and confused with a trauma since the first visit to dentist while the patient had primary teeth. Then after each time he went to dental visit, the diagnosis was dental caries in all his dentition.

The orthopantomogram at 8 years old showed the presence of unerupted lower second and third molars and upper second molar, normal pattern of eruption of all teeth, without signs of periodontal injuries. A generalized thinning of enamel on all tooth surfaces was detected (Figure 1).

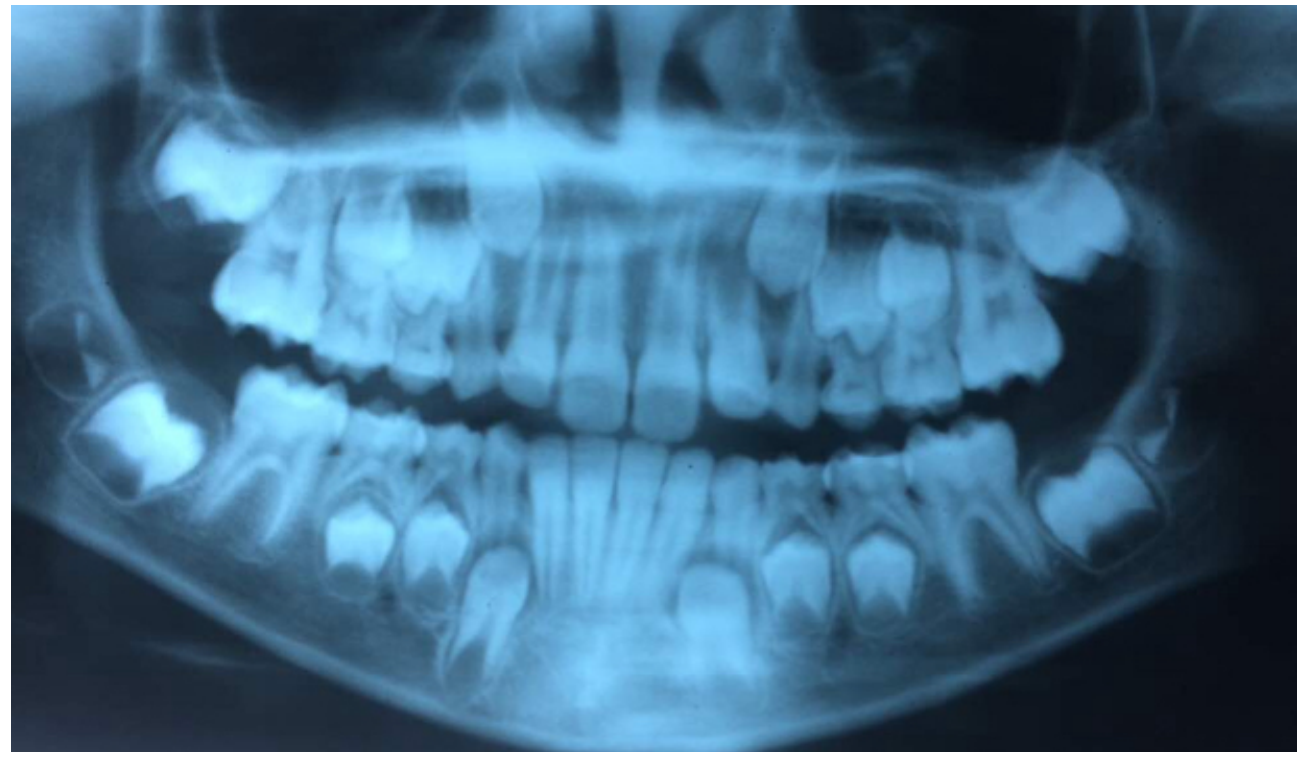

Figure 1. Orthopantomogram at 8 years old 
The mother provided consent for treatment and publication of the case. Diagnosis was done through history, clinical examination and imaging. The Al type in this case report was classified according to the clinical features (phenotypes) and radiographic images. The patient showed: Hypoplasic Amelogenesis imperfect. Thin and smooth enamel was noted affecting both primary and permanent dentition. The color was discolored light cream with particular shapes with absence of enamel similar as pits in incisive and deep fissures in molars, phenotype described as a quantitative defect hypoplastic type of Amelogenesis imperfecta (Figure 2 y 3). The diagnosis of hypoplasia (type I Al) was made.
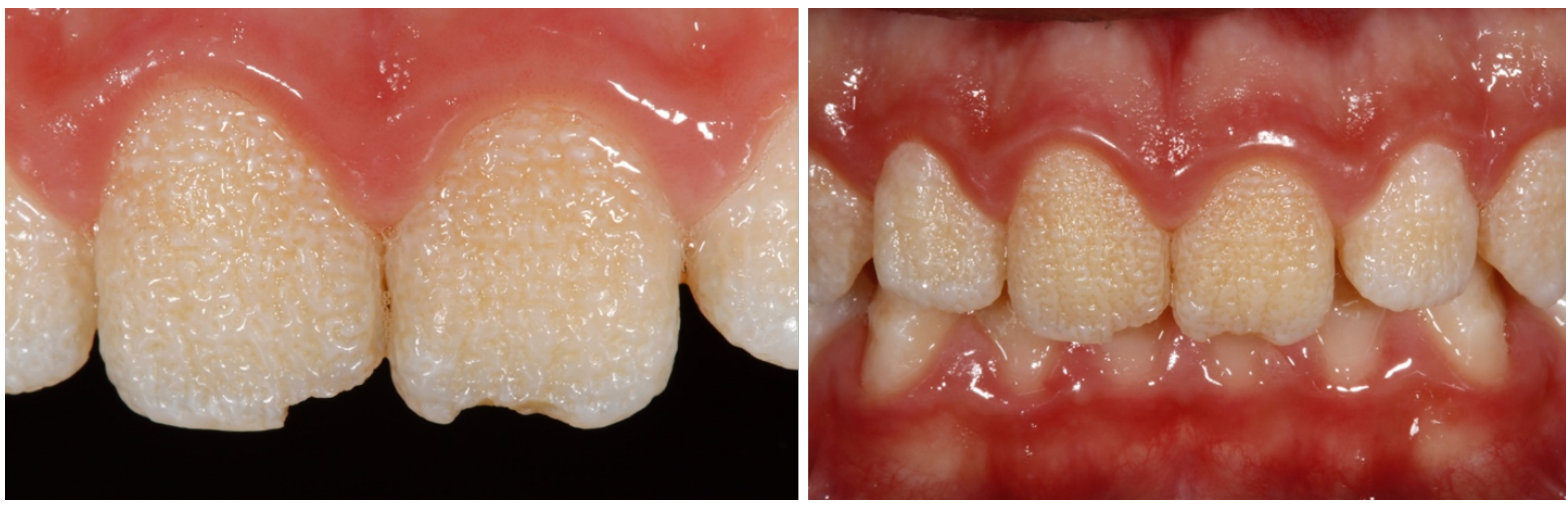

Figure 2. Frontal view of Hypoplasic Amelogenesis imperfecta

By: the authors
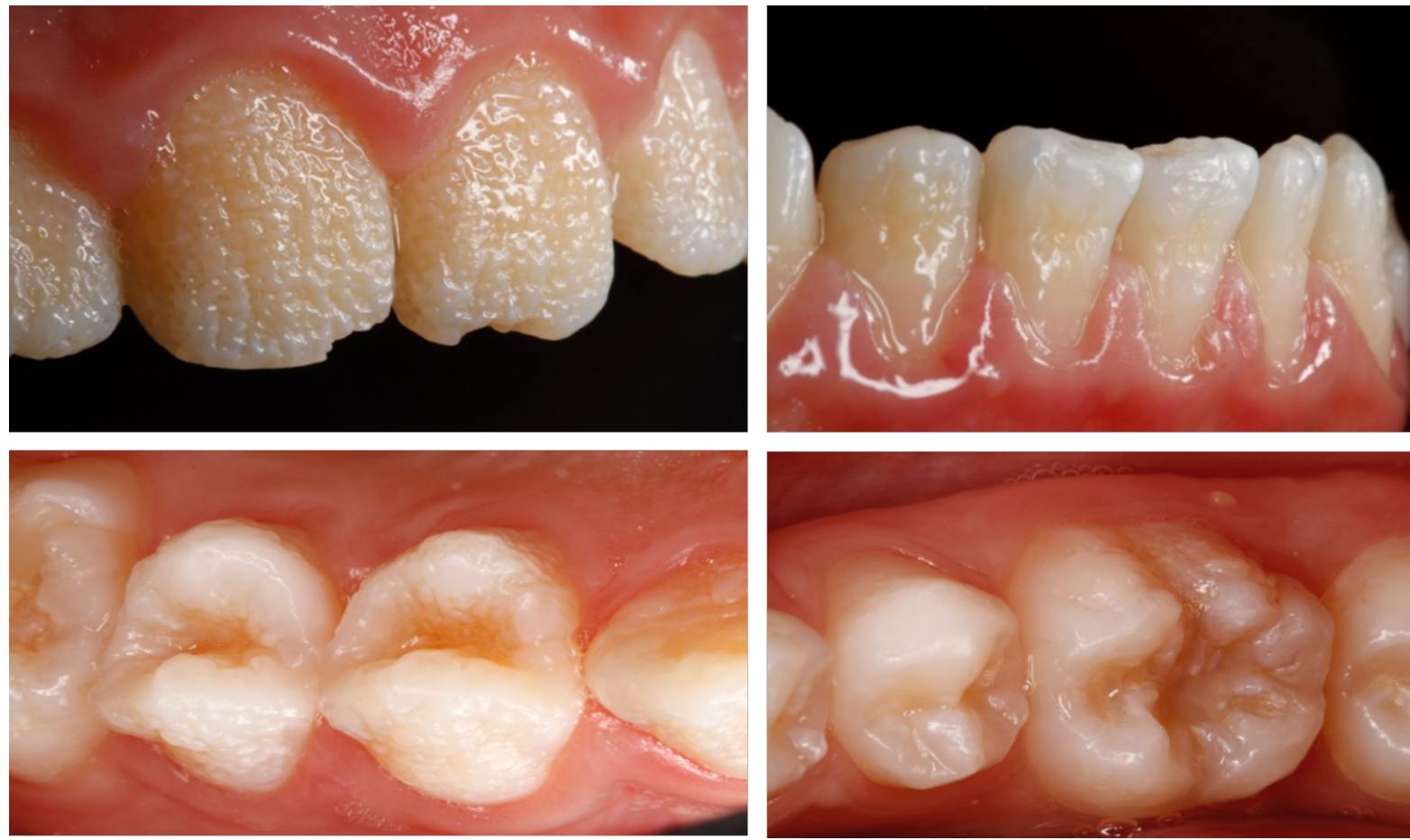

Figure 3. View of upper incisors, lower incisors, premolar and molar with Amelogenesis imperfecta

By: the authors 
Initially the treatment procedures included the diagnosis of Amelogenesis imperfecta done by a pediatric dentist, who refer the teenager FOR an evaluation with a pediatric nephrologist. Following this, the patient was evaluated by a psychologist, who applied a projective Drawing of the Human Figure test, Koppitz method. The next intervention was the rehabilitation plan by a prosthodontic joined with a dental technician. The treatment plan was carried out in step by step fashion until positive results were reached.

\section{Intervention}

Histopathological reports confirms that when enamel hypoplasia is the predominant clinical finding, the enamel is reduced in thickness. The enamel-dentin junction may show exaggerated scalloping. Areas of homogeneous aprismatic enamel or fused indistinct prisms are seen ${ }^{18}$. The histology phenotype described by Witkop showed that the most marked defects in the enamel were seen in the outer half ${ }^{19}$. For these reasons it was proper to restauration with direct resin veneers.

Minimal preparation was performed on lateral incisors and canines. In the central incisors no preparation was done. Red ring fine diamond bur was used in proximal faces and gingival area, a preparation with a marginal chamber finish for was done. Chamfer preparation design was complete in remaining enamel, nothing in dentin.

After teeth preparation Ultradent ${ }^{\circledR}$ Ultrapack retractor cord was used with Ultradent ${ }^{\circledR}$ Fischer's Ultrapak packers. The adhesive technique includes deproteinization of the enamel with $5.25 \%$ sodium hypochlorite in solution for one minute and rinse. The enamel surface was treated with $35 \%$ phosphoric acid gel (Ultradent ${ }^{\circledR}$ ) for 10 seconds. Then it was rinsed with water for 30 seconds and the excess water was removed. The Ultradent ${ }^{\circledR}$ peak adhesive was applied, and then air dried during 20 seconds, and then it was light cured in accordance with the manufacturer's instructions. Freehand direct resin veneers, Ultradent brand, Vit-l-escence ${ }^{\circledR}$. Color A2, A1, TM were done and polished with Jiffy System by Ultradent ${ }^{\circledR}$, only mechanical. Polishing system was made with Jiffy System by Ultradent ${ }^{\circledR}$, only mechanical. No final liquid was used. Finally, the occlusion was evaluated (Figure 4). In premolars and molars no intervention was done, because of the hygiene of the patient although is not common to leave the posteriors teeth without restorations.
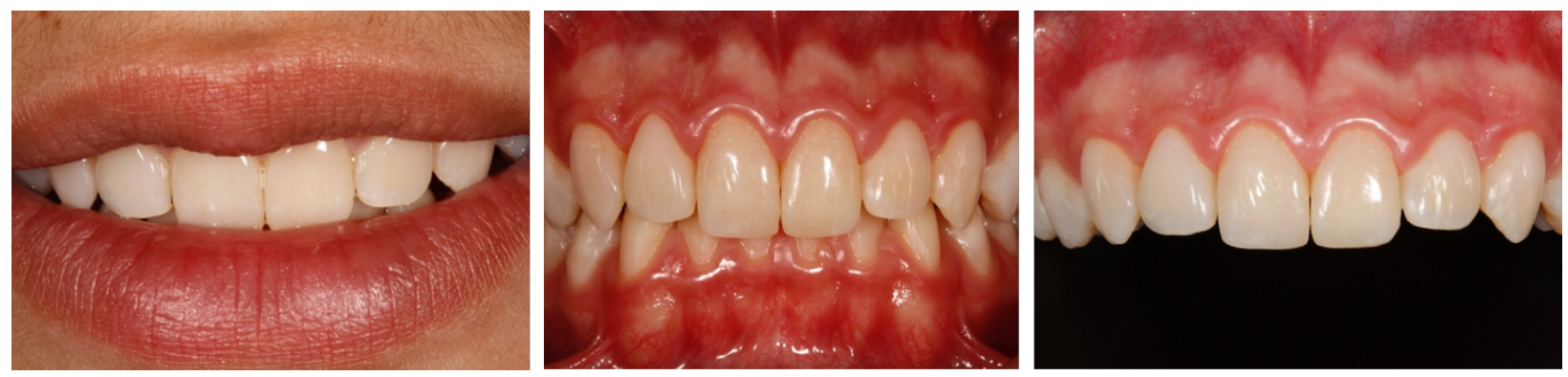

Figure 4. Frontal view of completed treatment with direct resin veneers

By: the authors 
A 12-month follow-up with clinical and radiographic examinations revealed no evidence of any undesirable effects of the treatment on the restored teeth or their supporting tissues.

\section{DISCUSSION}

This case report showed the challenge represented in the management of a patient with Al for the clinician. Although it has limitations, the dentist can see many variables that must be taken into consideration to provide a comprehensive intervention for the patient with this condition. The patient with Al not only has an enamel defect with problems of color or shape, but there are also lots of complications, that they may have during all their life and the scope giving after a dental treatment are numerous. The treatment options vary considerably depending on several factors such as the age of the patient, socio-economic status, periodontal condition, loss of tooth structure, severity of the disorder, and, most importantly, the patient's cooperation. The clinician has to consider the long-term prognosis of the outcome ${ }^{20}$. Treatment of a patient with $\mathrm{Al}$ presents a real problem from both functional and esthetic points of view. An esthetic intervention will also result in an improvement in the patient's quality of life ${ }^{21}$.

Treatment not only restored function and esthetic, but also showed a positive psychological impact and thereby improved perceived quality of life ${ }^{22}$. Particularly in this case because the recovery of the patient's self-confidence was allowed by a multidisciplinary team. Studies in children with enamel defects have showed prior to treatment, that children reported high levels of worry, embarrassment and a perception that their teeth looked yellow and discolored. Following treatment, children thought their teeth looked much better, felt happier and more confident. They also felt very positive about their clinical experiences, rating the staff as extremely friendly and kind and reporting that procedures were clearly explained. Simple non-invasive dental treatment can have a positive effect on appearance-related satisfaction ${ }^{23}$.

The preventive, psychological, and curative measures of a young child with $\mathrm{Al}$ are notable ${ }^{25}$. The successful management of $\mathrm{Al}$ during childhood requires the cooperation and motivation of the patient and parents ${ }^{24}$. The esthetic and psychosocial aspects of a child growing are extremely important. It is known that young people may make negative psychosocial judgements on the basis of enamel appearance ${ }^{25}$.

On the other hand, when rehabilitation area is involved, intervention includes a wide variety of options like removal of surface stains, reducing sensitivity, maintaining the vertical dimension of occlusion, and the esthetics ${ }^{22}$. Indirect composite restorations can be a valuable tool for improving occlusion, esthetics and function in the treatment of children and adolescents. In most cases, direct composite fillings can be placed. However, in severe cases, these restorations may be more challenging and error-prone, especially when occlusal adjustments are necessary. Since composite materials do not require specific lamination strength and are easy to repair, they can be applied using the indirect technique, enablingthe conservation of more sound hard tissue than is possible when conventional restorations are used ${ }^{26}$. Previous reports indicate indirect restorations should be preferred over direct restorations in patients with $\mathrm{Al}^{27}$. 
Composite resin restorations have been advocated to mask discoloration and improve dental esthetics with minimal or no tooth preparation to preserve tooth structure and provide satisfactory esthetics ${ }^{28}$. In this case report direct restorations were an excellent option for the patient because the greatest challenge was in the anterior sector. In the posterior zone, there was no intervention due to the poor oral hygiene of the patient.

Attention should first be given to the patient's level of oral hygiene and dietary habits, which can compromise the rehabilitation procedures. Poor oral hygiene is a recognized problem in patients with $\mathrm{Al}$, due to the rough enamel surface which causes biofilm retention and the sensitivity experienced when brushing ${ }^{29}$. Therefore, oral hygiene instructions are essential for the successful treatment ${ }^{30}$. Although a study by Kammoun et al. showed that hypoplasic Al patients have a low DMFT index, an alkaline $\mathrm{pH}$ of saliva enriched with Bacillus spp, Enterococcus faecalis and Enterococcus faecium and dental tissues more easily invaded by Lactobacilli than Streptococci. The combination of these bacteria seems to give Al patients protection against dental caries ${ }^{31}$. However, dental treatment in patients with $\mathrm{Al}$ should focus on restorations as soon as possible ${ }^{27}$.

It is important to highlight that the longevity of dental restorations in patients with $\mathrm{Al}$ is limited. Pousette et al. compared oral health and longevity of dental restorations in a group of young patients with $\mathrm{Al}$ to a control group. They included 82 patients with $\mathrm{Al}, 40$ boys and 42 girls, 6 to 25 years old and a control group matched in age, gender and residential area. The longevity of dental restorations was significantly lower in the patients with Al. Patients with hypomineralized/hypomaturized Al have restorations of shorter longevity than those with hypoplasic $\mathrm{Al}^{32}$. In this particular case with hypoplasic $\mathrm{Al}$, restorations can be durable due to the specific type of defect. Although further laboratory and clinical studies should be achieved to investigate the performance of minimally invasive indirect restorations bonded to enamel in patients with $\mathrm{Al}^{27}$.

Management is relevant at various stages of the developing dentition but it also should be considered the compromises which may have to be made depending on the child's ability to cope. The importance of early diagnosis, prevention and the benefits of a multi-disciplinary approach are $\mathrm{crucial}^{33}$.

Early recognition followed by appropriate preventive and restorative care is essential in the successful management of AI. A multidisciplinary approach with careful planning from early childhood will maximize the treatment options available for the permanent dentition and optimize the final outcome ${ }^{6}$.

There is an urgent need of knowledge of causes, diagnosis and treatment of $\mathrm{Al}$ and also to detect the differential diagnosis with fluorosis, molar incisive hypomineralization or isolate hypoplasia. Even among the pediatric dentist who are the first to receive these patients, there is a need to improve the comprehension of the enamel defects ${ }^{34}$.

This case has a strength in the fact that the caregivers are aware to find a solution and are advocated to keep to all the appointments. Although the full rehabilitation of the patient was very expensive, we found grants with Ultradent ${ }^{\circledR}$. The limitations of this case 
report are the challenges that represents covering all the patient's needs and the late diagnosis done. It is important to underline that the interdisciplinary management needs to contemplate a genetic shift to identify potential mutations in these patients. Although the cost is expensive, it is necessary to involve this kind of test to have better follow-up and diagnosis of the family.

Another important consideration of patients with $\mathrm{Al}$ is the association between renal disease and $\mathrm{Al}$ which has been reported decades ago ${ }^{35,36}$. The contributions provided by this case are represented in the fact that this information will help dentists to identify this condition and understand the importance to refer patients with amelogenesis imperfecta to nephrologists as soon as possible. Pediatric dentists should obtain a detailed family history and past medical history with particular reference to urinary tract and should be refer for medical examination including renal function test and ultrasonography. The same recommendation is done to pediatric nephrologists that need to know the association that exists between amelogenesis imperfecta and renal disease ${ }^{37,38}$.

This treatment showed to improve occlusion, esthetics and self-image of the teenager. The satisfactory clinical result has made it possible to avoid more invasive and expensive treatments.

\section{ACKNOWLEDGEMENTS}

We thank Mr. Andres Ospina, representant of Dental Mejia for the donation of Ultradent materials to all the treatment.

\section{CONFLICTS OF INTEREST}

The authors declare that they have no conflicts of interest.

\section{CORRESPONDING AUTHOR}

Maria Gabriela Acosta de Camargo

gabrieladecamargo@yahoo.com - macosta@uc.edu.ve

Urbanización Terrazas del Country Res Villas del Country Casa \# 15.

(+58) 4144287424

Universidad de Carabobo

Valencia, Estado Carabobo, Venezuela 


\section{REFERENCES}

1. Simancas-Escorcia V, Natera A, Acosta-de Camargo MG. Genes involved in amelogenesis imperfecta. Part I. Rev Fac Odontol Univ Antioq. 2018; 30(1): 105-20. DOI: http://dx.doi.org/10.17533/udea.rfo. v30n1a10

2. Kim YJ, Kim YJ, Kang J, Shin TJ, Hyun HK, Lee SH, Lee ZH et al A novel AMELX mutation causes hypoplastic amelogenesis imperfecta. Arch Oral Biol. 2017; 76: 61-5. DOI: https://doi.org/10.1016/j. archoralbio.2017.01.004

3. Crawford PJ, Aldred M, Bloch-Zupan A. Amelogenesis imperfecta. Orphanet J Rare Dis. 2007; 2: 17.

4. Leevailoj C, Lawanrattanakul S, Mahatumarat K. Amelogenesis Imperfecta: case study. Oper Dent. 2017; 42(5): 457-69. DOI: https://doi.org/10.2341/13-256-s

5. Ramos AL, Pascotto RC, Filho LI, Hayacibara RM, Boselli G. Interdisciplinary treatment for a patient with open-bite malocclusion and amelogenesis imperfecta. Am J Orthod Dentofacial Orthop. 2011; 139(4 Suppl): 145-53. DOI: https://doi.org/10.1016/j.ajodo.2009.05.031

6. Ayers KM, Drummond BK, Harding WJ, Salis SG, Liaton PN. Amelogenesis imperfecta: multidisciplinary management from eruption to adulthood. Review and case report. N Z Dent J. 2004; 100(4): 101-4.

7. Smith CEL, Poulter JA, Antanaviciute A, Kirkham J, Brookes SJ, Inglehearn CF et al. Amelogenesis imperfecta: genes, proteins, and pathways. Front Physiol. 2017; 8: 435. DOI: https://dx.doi. org/10.3389\%2Ffphys.2017.00435

8. Witkop CJ Jr. Amelogenesis imperfecta, dentinogenesis imperfecta and dentin dysplasia revisited: problems in classification. J Oral Pathol. 1998; 17(9-10): 547-53. DOI: https://doi.org/10.1111/j.1600-0714.1988. tb01332.x

9. Aldred MJ, Savarirayan R, Crawforf PJ. Amelogenesis imperfecta: a classification and catalogue for the $21 \mathrm{st}$ century. Oral Disease. 2003; 9(1): 19-23. DOI: https://doi.org/10.1034/j.1601-0825.2003.00843.x

10. Lil L, Saiyin W, Zhang H, Wang S, Xu Q, Qin C et al. FAM20A is essential for amelogenesis, but is dispensable for dentinogenesis. J Mol Histol. 2019; 50(6): 581-91. DOI: https://dx.doi.org/10.1007\%2Fs10735-01909851-x

11. Chauharry M, Dixit S, Singh A, Kunte S. Amelogenesis imperfecta: report of a case and review of literature. J Oral Maxillofac Pathol. 2009; 13(2): 70-7. DOI: https://dx.doi.org/10.4103\%2F0973-029X.57673

12. Sabandal MM, Schäfer E. Amelogenesis imperfecta: review of diagnostic findings and treatment concepts. Odontology. 2016; 104(3): 245-56. DOI: https://doi.org/10.1007/s10266-016-0266-1

13. Poulsen S, Gjorup H, Haubek D, Haubek D, Haukali G, Hintze H et al. Amelogenesis imperfecta: a systemic literature review of associated dental and oro-facial abnormalities and their impact on patients. Acta Odontol Scand. 2008; 66(4): 193-99. DOI: https://doi.org/10.1080/00016350802192071

14. Arshad M, Shirani G, Mahgoli HA, Vaziri N. Rehabilitation of a patient with amelogenesis imperfecta and severe open bite: a multidisciplinary approach. Clin Case Rep. 2018; 7(2): 275-83. DOI: https://dx.doi. org/10.1002\%2Fccr3.1966

15. Patel M, McDonnell ST, Iram S, Chan MF. Amelogenesis imperfecta: lifelong management. Restorative management of the adult patient. BR Dent J. 2013; 215(9): 449-57. DOI: https://doi.org/10.1038/ sj.bdj.2013.1045 
16. Coffield KD, Phillips C, Brady M, Roberts MW, Strauss RP, Wright JT. The psychosocial impact of developmental dental defects in people with hereditary amelogenesis imperfecta. J Am Dent Assoc. 2005; 136(5): 620-30. DOI: https://doi.org/10.14219/jada.archive.2005.0233

17. Tortolero MB. Self-esteem in children and teenagers with tooth disorders: literature review. ODOUS. 2015; 16(2): 58-70.

18. Witkop CJ, Sauk KK. Heritable defects of enamel. In: Stewart RE, Prescott CH (editors). Oral facial genetics. St Louis: C.V. Mosby; 1976.

19. Witkop CJ. Heriditary defects in enamel and dentin. Acta Genet Stat Med. 1957; 7(1): 236-9. DOI: https:// doi.org/10.1159/000150974

20. Sholapurkar AA, Joseph RM, Varghese JM, Neelagiri K, Acharya SR, Hegde V et al. Clinical diagnosis and oral rehabilitation of a patient with amelogenesis imperfecta: a case report. J Contemp Dent Pract. 2008; 9(4): 92-8.

21. Akin $\mathrm{H}$, Tasveren S, Yeler DY. Interdisciplinary approach to treating a patient with amelogenesis imperfecta: a clinical report. J Esthet Restor Dent. 2007; 19(3): 131-5. DOI: https://doi.org/10.1111/ j.1708-8240.2007.00083.x

22. Marquezin MC, Zancopé BR, Pacheco LF, Gavião MB, Pascon FM. Aesthetic and functional rehabilitation of the primary dentition affected by amelogenesis imperfecta. Case Rep Dent. 2015; 2015: 790890. DOI: https://doi.org/10.1155/2015/790890

23. Rodd HD, Abdul-Karim A, Yesudian G, O'Mahony J, Marshman Z. Seeking children's perspectives in the management of visible enamel defects. Int J Paediatr Dent. 2011; 21(2): 89-95. DOI: https://doi. org/10.1111/j.1365-263x.2010.01096.x

24. Lourenço Neto N, Paschoal MA, Kobayashi T Y, Rios D, Silva SM. Oral rehabilitation of a child with amelogenesis imperfect. Journal of Health Science. 2010; 28(3): 246-8.

25. Craig AS, Baker SR, Rodd HD. How do children view other children who have visible enamel defects? Int J Paediatr Dent. 2015; 26(6): 399-408. DOI: https://doi.org/10.1111/ipd.12146

26. Soliman S, Meyer-Marcotty P, Hahn B, Halbleib K, Krastl G. Treatment of an adolescent patient with Dentinogenesis Imperfecta using indirect composite restorations: a case report and literature review. J Adh Dent. 2018;2 0(4): 345-54. DOI: https://doi.org/10.3290/j.jad.a40991

27. Strauch $\mathrm{S}$, Hahnel S. Restorative treatment in patients with Amelogenesis imperfect: a review. J Prosthodont. 2018; 27(7): 618-23. DOI: https://doi.org/10.1111/jopr.12736

28. Sönmez IS, Aras S, Tunç ES, Küçükeşmen C. Clinical success of deproteinization in hypocalcified amelogenesis imperfecta. Quintessence Int. 2009; 40(2): 113-8.

29. Visram S., McKaig S. Amelogenesis imperfecta, clinical presentation and management: a case report. Dental Update. 2006; 33(10): 612-6. DOI: https://doi.org/10.12968/denu.2006.33.10.612

30. Bouvier D, Duprez JP, Bois D. Rehabilitation of young patients with amelogenesis imperfecta: a report of two cases. ASDC J Dent Child. 1996; 63(6): 443-47.

31. Kammoun R, Zmantar T, Labidi A, Abbes I, Mansour L, Ghoul-Mazgar S. Dental caries and hypoplastic amelogenesis imperfecta: clinical, structural, biochemical and molecular approaches. Microb Pathog. 2019; 135: 103615. DOI: https://doi.org/10.1016/j.micpath.2019.103615

32. Pousette-Lundgren G, Dahllof G. Outcome of restorative treatment in young patients with amelogenesis imperfecta: a cross-sectional, retrospective study. J Dent. 2014; 42(11): 1382-9. DOI: https://doi. org/10.1016/j.jdent.2014.07.017 
33. McDonald S, Arkutu N, Malik K, Gadhia K, McKaig S. Managing the paediatric patient with Amelogenesis Imperfecta. Br Dent J. 2012; 212(9): 425-8. DOI: https://doi.org/10.1038/sj.bdj.2012.366

34. Acosta-de Camargo MF, Natera A. Level of knowledge concerning enamel defects and their treatment among pediatric dentists. Rev Odontopediatr Latinoam. 2017; 7(1): 25-35. DOI: https://doi.org/10.47990/ alop.v7i1.128

35. MacGibbon D. Generalized enamel hypoplasia and renal dysfunction. Aust Dent J. 1972, 17(1): 61-3. DOI: https://doi.org/10.1111/j.1834-7819.1972.tb02747.x

36. De la Dure-Molla M, Quentric M, Yamaguti PM, Acevedo AC, Mighell AJ, Vikkula M et al. Pathognomonic oral profile of Enamel Renal Syndrome (ERS) caused by recessive FAM20A mutations. Orphanet J Rare Dis. 2014; 9.

37. Hunter L, Addy LD, Knox J, Drage N. Is amelogenesis imperfect an indication for renal examination? Int J Paediatr Dent. 2007; 17(1): 62-5. DOI: https://doi.org/10.1111/j.1365-263x.2006.00782.x

38. Elizabeth J, Lakshmi Priya K, Umadevi R, Ranganathan K. Amelogenesis imperfecta with renal disease: a report of two cases. J Oral Pathol Med. 2007; 36(10): 625-8. DOI: https://doi.org/10.1111/j.16000714.2007.00615.x 